\title{
Vascular Smooth Muscle Cells in Culture Express Tumor Necrosis Factor- $\alpha$ That Suppresses Collagen Synthesis Depending on Cell Density
}

\author{
Toshiyuki Kaji, ${ }^{* a}$ Syouichi Hiraga, ${ }^{a}$ Chika Yamamoto, ${ }^{a}$ Yasuyuki Fujiwara, ${ }^{a}$ \\ Yoshimichi Ueda, ${ }^{b}$ Fumiko Zisaki, ${ }^{b}$ Kazushi Iwata, ${ }^{c}$ Shogo Katsuda, ${ }^{b}$ and Isao Nakanishi ${ }^{d}$ \\ ${ }^{a}$ Department of Environmental Health, Faculty of Pharmaceutical Sciences, Hokuriku University, Ho-3 Kanagawa-machi, Kanazawa \\ 920-1181, Japan, 'Department of Pathology, Kanazawa Medical University, 1-1 Daigaku, Uchinada-machi, Kahoku-gun, Ishikawa \\ 920-0293, Japan, 'Biopharmaceutical Department, Fuji Chemical Industries, Ltd., 530 Chokeiji, Takaoka, Toyama 933-8511, Japan, \\ and ${ }^{d}$ Department of Pathology, School of Medicine, Kanazawa University, 13-1, Takara-machi, Kanazawa 920-8640, Japan
}

(Received November 18, 2002; Accepted January 31, 2003)

\begin{abstract}
Tumor necrosis factor- $\alpha(\mathrm{TNF}-\alpha)$ has been implicated in the pathogenesis of atherosclerosis through influence on vascular smooth muscle cell behavior. However, little is known about the expression and function of endogenous TNF- $\alpha$ in the cells. Dense and sparse cultures of bovine aortic smooth muscle cells were prepared and the expression of TNF- $\alpha$ and regulation of collagen synthesis by endogenous TNF- $\alpha$ were investigated. The results indicate that dense and sparse vascular smooth muscle cells express endogenous TNF- $\alpha$ that suppresses the synthesis of collagen (types I and III) only when the cell density is high; suppression was also observed in human and rabbit aortic smooth muscle cells. Transforming growth factor- $\beta$ stimulated collagen synthesis in bovine aortic smooth muscle cells and the stimulation was significantly suppressed by endogenous TNF- $\alpha$ when cell density was high. The present data suggest that vascular smooth muscle cells express endogenous TNF- $\alpha$ that is involved in the suppressive regulation of collagen synthesis depending on the cell density.
\end{abstract}

Key words — atherosclerosis, collagen, tumor necrosis factor- $\alpha$, smooth muscle cell, vascular smooth muscle cell

\section{INTRODUCTION}

Tumor necrosis factor- $\alpha$ (TNF- $\alpha)$ is one of the cytokines that may be involved in the progression and formation of atherosclerosis. ${ }^{1)}$ It is well known that the cytokine regulates vascular endothelial cell functions. TNF- $\alpha$ exhibits cytotoxicity and inhibits the proliferation of the cells. ${ }^{2)}$ In addition, the cytokine inhibits the secretion of tissue plasminogen activator, but stimulates that of plasminogen activator inhibitor type-1. ${ }^{3)}$ These results indicate that TNF- $\alpha$ may contribute to the pathogenesis of atherosclerosis through injury to the endothelial cell monolayer and reduction of fibrinolytic activity in blood.

Expression of TNF- $\alpha$ is observed in atherosclerotic plaques, and the main source of the cytokine is

\footnotetext{
*To whom correspondence should be addressed: Department of Environmental Health, Faculty of Pharmaceutical Sciences, Hokuriku University, Ho-3 Kanagawa-machi, Kanazawa 920 1181, Japan. Tel. \& Fax: +81-76-229-6208; E-mail: t-kaji@ hokuriku-u.ac.jp
}

macrophages. ${ }^{4)}$ However, vascular smooth muscle cells also express TNF- $\alpha$ in human and rabbit atherosclerotic vascular wall. ${ }^{5-8)}$ Although the expression has been postulated to be a pathological event under certain conditions such as atherosclerosis, we hypothesized that normal vascular smooth muscle cells also express TNF- $\alpha$ that regulates their functions through an autocrine mechanism. Although TNF- $\alpha$ expression was observed in cultured vascular smooth muscle cells stimulated by anisomycin and bacterial lipopolysaccharide ${ }^{9)}$ or by low-density lipoprotein, ${ }^{6}$ constitutive expression and function of TNF- $\alpha$ in the cells have been incompletely understood.

On the other hand, in atherosclerotic vascular arteries, excess amounts of extracellular matrix is deposited in the intima. ${ }^{10)}$ The extracellular matrix is composed of collagens, elastin, proteoglycans, and other structural glycoproteins, ${ }^{11)}$ and vascular smooth muscle cells are the predominant cell type responsible for the synthesis and secretion of the extracellular matrix components in the arterial wall. ${ }^{12)} \mathrm{Col}-$ 
lagens are the major component of the human arterial wall ${ }^{13)}$ and increase depending on the progression of atherosclerosis ${ }^{14)}$; types I, III, IV, V, and VI collagens are in general present ${ }^{15)}$ and increase in atherosclerotic plaques. ${ }^{16)}$ Although quantitative changes in minor collagens are characteristic of atherosclerosis, the synthetic phenotype of vascular smooth muscle cells predominantly synthesizes type I collagen. ${ }^{17)}$

In our previous study, it was shown that TNF- $\alpha$ regulates the synthesis and sulfation of glycosaminoglycans in cultured vascular smooth muscle cells. ${ }^{18,19)}$ Recently, it has been found that TNF- $\alpha$ strongly suppresses the synthesis of collagens in the cells. ${ }^{20)}$ The present study was undertaken to address the questions of whether cultured vascular smooth muscle cells express endogenous TNF- $\alpha$ and whether the cytokine regulates the synthesis of collagens via an autocrine mechanism in the cells.

\section{MATERIALS AND METHODS}

Materials — Bovine aortic smooth muscle cells were a gift from Drs. Katsuo Sueishi and Yutaka Nakashima (Department of Pathology, Kyushu University Graduate School of Medical Sciences, Fukuoka Japan). Human aortic smooth muscle cells were purchased from Kurabo (Osaka, Japan). Rabbit aortic smooth muscle cells were obtained from the thoracic aorta of male rabbits weighing about $2.5 \mathrm{~kg}$ as described previously. ${ }^{21)}$ RPMI 1640 medium and fetal bovine serum (FBS) were purchased from Nissui Pharmaceutical (Tokyo, Japan) and Bioproducts (Walkersville, MD, U.S.A.), respectively. Tissue culture plates and dishes were from Iwaki (Chiba, Japan). Blotting membranes were obtained from Atoo (Tokyo, Japan). L-[2,3,4,5$\left.{ }^{3} \mathrm{H}\right]$ Proline $(4070 \mathrm{GBq} / \mathrm{ml})$ was from Moravek Biochemicals (Brea, CA, U.S.A.). TNF- $\alpha$ neutralizing antibody (TNF- $\alpha \mathrm{Ab}$ ), rabbit IgG, and peroxidase-labeled goat antibody against rabbit IgG were purchased from Genzyme (Cambridge, MA, U.S.A.), East Acres Biologicals (Southbridge, MA, U.S.A.) and Dako (Glostrup, Denmark), respectively. Pepsin and bovine serum albumin fraction V (BSA) were from Worthington Biochemical (Freehold, NJ, U.S.A.) and Miles (Kankakee, IL, U.S.A.), respectively. Collagenase type VII, Tris base, $\mathrm{N}$ ethylmaleimide, phenylmethansulfonyl fluoride, and pepstatin A were obtained from Sigma Chemical (St. Louis, MO, U.S.A.). Transforming growth factor- $\beta_{1}$
(TGF- $\beta$ ) derived from human platelets and 3aminopropionitrile (BAPN) were from Wako Pure Chemical Industries (Osaka, Japan). Lab-Tek tissue culture chamber slides were purchased from Nunc (Naparville, IL, U.S.A.). Primers and probe for reverse transcription-polymerase chain reaction (RTPCR) were from Hokkaido System Science (Sapporo, Japan). DIG Luminescent Detection kits were obtained from Boehringer-Mannheim (Germany). Other reagents were from Nacalai Tesque (Kyoto, Japan).

Preparation of Dense and Sparse Cultures of Vascular Smooth Muscle Cells — Bovine, human, and rabbit aortic smooth muscle cells were cultured in RPMI 1640 medium supplemented with $10 \% \mathrm{FBS}$ in 6-well culture plates at $37^{\circ} \mathrm{C}$ in $5 \% \mathrm{CO}_{2}$ in air until confluent (dense cultures). Separately, bovine aortic smooth muscle cells were plated at $5 \times 10^{3}$ cell $/ \mathrm{cm}^{2}$ in 6 -well plates and cultured for $24 \mathrm{hr}$ in RPMI 1640 medium supplemented with $10 \%$ FBS (sparse cultures).

Immunocytochemistry —— Dense and sparse cultures of bovine aortic smooth muscle cells were prepared on Lab-Tek chamber slides in RPMI 1640 medium supplemented with $0.1 \%$ BSA and immunostained with TNF- $\alpha$ Ab using an avidin-biotin-peroxidase method. ${ }^{22)}$ Briefly, the cells were gently washed with calcium and magnesium-free phosphate-buffered saline (CMF-PBS) and treated with $0.3 \%$ hydrogen peroxide in methanol for $30 \mathrm{~min}$ to inactivate endogenous peroxidases. Nonspecific binding sites were blocked by treatment with $10 \%$ normal goat serum in PBS for $30 \mathrm{~min}$ at room temperature. The cells were exposed to TNF- $\alpha \mathrm{Ab}$ (primary antibody) for $16 \mathrm{hr}$ at $4^{\circ} \mathrm{C}$ in a humidified chamber. They were then gently washed with PBS and incubated sequentially with a biotinylated goat antibody against rabbit IgG for $30 \mathrm{~min}$ at room temperature, PBS for $15 \mathrm{~min}$, and avidin-biotin-peroxidase complex for $30 \mathrm{~min}$. The complex was developed by exposing the cells to a solution of 3,3'diaminobenzidine-4 hydrochloric acid $(\mathrm{HCl})$ $(0.5 \mathrm{mg} / \mathrm{ml}$ in $0.05 \mathrm{M}$ Tris-HCl, $\mathrm{pH} 7.6$, containing $0.03 \% \mathrm{H}_{2} \mathrm{O}_{2}$ ) until a brown stain appeared. The cells were then rinsed with tap water for an additional $10 \mathrm{~min}$ and counterstained with hematoxylin. Negative controls included replacement of the primary antibody with PBS.

RT-PCR — To determine the gene expression of TNF- $\alpha$, poly $(\mathrm{A})^{+}$RNA was isolated from dense bovine aortic smooth muscle cells, and TNF- $\alpha$ mRNA analyzed by RT-PCR. The amount of poly $(\mathrm{A})^{+} \mathrm{RNA}$ 
templates and the cycle number for amplification were $30 \mathrm{ng}$ and 35 cycles, respectively. After RT$\mathrm{PCR}$, an aliquot of the reaction mixture was electrophoresed on a $2 \%$ agarose gel and stained with $0.001 \%$ ethidium bromide for $30 \mathrm{~min}$. The sequences of the upstream and downstream primers were $5^{\prime}$ CAGAGGGAAGAGTTCCCCAG- ${ }^{\prime}$ and $5^{\prime}$-CCTTGGTCTGGTAGGAGACG-3', respectively. The size of the PCR products was 325 base pairs. Southern blot analysis of the RT-PCR products was performed on a blotting membrane with a digoxygeninlabeled probe (5'-CTTGAGGGTTTGCTACAACATGGG-3') and the band was visualized using a DIG Luminescent Detection kit.

Western Blot Analysis — Dense cultures of bovine aortic smooth muscle cells were extracted with $50 \mathrm{mM}$ Tris- $\mathrm{HCl}$ buffer solution (pH 7.5) containing $10 \%$ glycerol, $5 \mathrm{mM}$ magnesium acetate, $0.2 \mathrm{mM}$ EDTA, $1 \mathrm{mM}$ phenylmethanesulfonyl fluoride, and $1 \%$ sodium dodecyl sulfate. Sodium dodecyl sulfatepolyacrylamide gel electrophoresis (SDS-PAGE) was performed according to the procedure of Laemmli ${ }^{23)}$ on an acrylamide $15 \%$ slab gel. The gel was transferred to nitrocellulose membranes with a semidry transfer apparatus (Atoo, AE-6677). The membrane was blocked and exposed to a primary antibody against TNF- $\alpha$ (TNF- $\alpha$ Ab, diluted $1: 250)$ for $1 \mathrm{hr}$ at room temperature. After incubation of the blot with horseradish peroxidase-linked protein A, bands that bound to the primary antibody were visualized using an enzyme-linked chemoluminescence procedure.

Incorporation of $\left[{ }^{3} \mathrm{H}\right]$ Proline into CollagenaseDigestible Proteins and Noncollagenous Proteins — Dense and sparse cultures of vascular smooth muscle cells were incubated at $37^{\circ} \mathrm{C}$ for 6 , 12,24 or $48 \mathrm{hr}$ in $1 \mathrm{ml}$ of RPMI 1640 medium with TNF- $\alpha$ Ab $(100,250,500,750$ or $1000 \mathrm{U} / \mathrm{ml})$ or rabbit $\operatorname{IgG}(1 \mathrm{mg} / \mathrm{ml})$ with or without TGF- $\beta(10 \mathrm{ng} /$ $\mathrm{ml})$ in the presence of $1 \% \mathrm{BSA}$, ascorbic acid $(100 \mu \mathrm{M}), \mathrm{BAPN}(500 \mu \mathrm{M})$ and $\left[{ }^{3} \mathrm{H}\right]$ proline $(37 \mathrm{kBq} /$ $\mathrm{ml})$. The cells were scraped off with a rubber policeman with the conditioned medium and the culture wells were washed with $1 \mathrm{ml}$ of ice-cold CMFPBS; the wash was combined with the cell suspension. The cell homogenate was prepared by sonication of the cell suspension, and $0.5 \mathrm{ml}$ of ice-cold $25 \%$ trichloroacetic acid was added to the homogenate after removal of free $\left[{ }^{3} \mathrm{H}\right]$ proline by dialysis. After standing for $5 \mathrm{~min}$ in an ice bath, the cell homogenate was centrifuged at $3000 \mathrm{rpm}$ for $10 \mathrm{~min}$ at $4{ }^{\circ} \mathrm{C}$ and the precipitate was analyzed using the collagenase digestion method of Peterkofsky and Diegelman ${ }^{24)}$ as follows: The precipitate was dissolved in $380 \mu \mathrm{l}$ of $0.04 \mathrm{~N} \mathrm{NaOH}$ and $20 \mu$ of $1.8 \mathrm{M}$ Tris-HCl buffer ( $\mathrm{pH}$ 7.4) was immediately added. An aliquot was incubated at $37^{\circ} \mathrm{C}$ for $2 \mathrm{hr}$ with collagenase $(250 \mu \mathrm{g} / \mathrm{ml})$ in the presence of $1.9 \mathrm{mM}$ $\mathrm{CaCl}_{2}, 7.8 \mathrm{mMN}$-ethylmaleimide, $6.3 \mathrm{mM}$ Tris base, and 0.25 M HEPES ( $\mathrm{pH} 7.2$ ) and then cooled in an ice bath after the addition of $0.25 \%$ tannic acid in $5 \%$ trichloroacetic acid. After centrifugation at $3000 \mathrm{rpm}$ for $10 \mathrm{~min}$ at $4^{\circ} \mathrm{C}$, the supernatant was harvested; after the addition of $0.25 \%$ tannic acid in $5 \%$ trichloroacetic acid, the precipitate was stirred and centrifuged at $3000 \mathrm{rpm}$ for $10 \mathrm{~min}$ at $4^{\circ} \mathrm{C}$. The supernatant was combined with the harvested supernatant (collagenase-digestible proteins; CDP) and the precipitate was dissolved in $0.5 \%$ SDS (noncollagenous proteins; NCP). The radioactivity incorporated into either CDP or NCP was determined by liquid scintillation counting. Separately, the cells were exposed to TNF- $\alpha$ or rabbit IgG combined with or without TGF- $\beta$ in a similar manner. The cells were harvested with a rubber policeman in the presence of CMF-PBS and the well was washed with CMFPBS; the wash was combined with the harvested cell suspension. The cell homogenate was prepared by sonication and analyzed for DNA content by the fluorometric method. ${ }^{25}$ ) The $\left[{ }^{3} \mathrm{H}\right]$ proline incorporation into CDP and NCP fractions was expressed as dpm/ $\mu \mathrm{g}$ DNA.

Collagen Type Analysis ${ }^{26)}$ — Dense cultures of bovine aortic smooth muscle cells were incubated at $37^{\circ} \mathrm{C}$ for $24 \mathrm{hr}$ with $1000 \mathrm{U} / \mathrm{ml} \mathrm{TNF}-\alpha \mathrm{Ab}$ in $2.5 \mathrm{ml}$ of RPMI 1640 medium containing $0.1 \%$ BSA, ascorbic acid $(100 \mu \mathrm{M})$ and BAPN $(500 \mu \mathrm{M})$ in $60-\mathrm{mm}$ culture dishes. After incubation, the medium was harvested and the cells were scraped off with a rubber policeman in the presence of $6 \mathrm{ml}$ of ice-cold CMF-PBS. The dish was washed with $6 \mathrm{ml}$ of icecold CMF-PBS, the wash was combined with the harvested cell suspension, and the cell homogenate was prepared by sonication. The cell homogenate and the conditioned medium were stirred for $12 \mathrm{hr}$ at $4{ }^{\circ} \mathrm{C}$ after the addition of ammonium sulfate $(176 \mathrm{mg} / \mathrm{ml})$ and $0.4 \mathrm{ml}$ of protease inhibitor solution (10 mM $N$-ethylmaleimide, $2 \mathrm{mM}$ EDTA, $1 \mathrm{mM}$ phenylmethanesulfonyl fluoride in $50 \mathrm{mM}$ Tris- $\mathrm{HCl}$ buffer, $\mathrm{pH}$ 7.5) and then centrifuged at $15000 \mathrm{rpm}$ for $1 \mathrm{hr}$ at $4^{\circ} \mathrm{C}$; the supernatant was discarded. The precipitate was dissolved in $3 \mathrm{ml}$ of $0.5 \mathrm{M}$ acetic acid and stirred for $6 \mathrm{hr}$ at $4{ }^{\circ} \mathrm{C}$ in the presence of pepsin $(0.16 \mathrm{mg} / \mathrm{ml})$. The $\mathrm{pH}$ of the solution was 

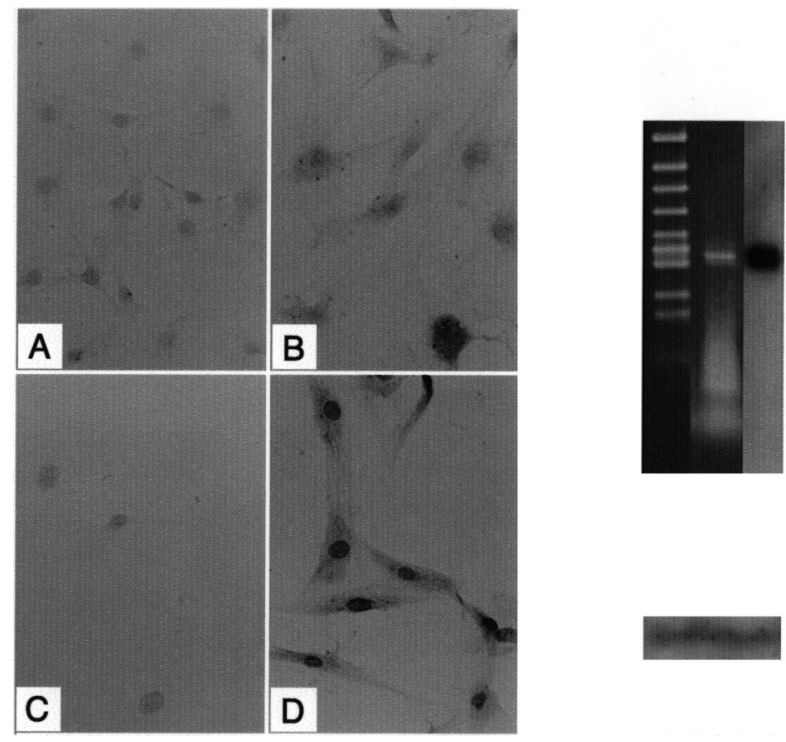

Fig. 1. Expression of Endogenous TNF- $\alpha$ in Cultured Vascular Smooth Muscle Cells

(A) Immunostaining of dense (a and b) and sparse (c and d) bovine aortic smooth muscle cells with an antibody specific for TNF- $\alpha$ (b and d). (B) RT-PCR for TNF- $\alpha$ mRNA (lane 1) and Southern blotting for the PCR products (lane 2) in dense bovine aortic smooth muscle cells. (C) Western blot analysis of TNF- $\alpha$ antigen in dense bovine aortic smooth muscle cells (lane 2). Lane 1 indicates recombinant human TNF- $\alpha$ as a standard.

adjusted to 7.4 with $2 \mathrm{M}$ Tris base and then pepstatin A $(50 \mu \mathrm{g} / \mathrm{ml})$ was added; the mixture was stirred at $4^{\circ} \mathrm{C}$ overnight and dialyzed against $0.5 \mathrm{M}$ acetic acid. The mixture was lyophilized and dissolved in $50 \mathrm{mM}$ Tris- $\mathrm{HCl}$ buffer ( $\mathrm{pH} 7.6$ ) containing $0.15 \mathrm{M} \mathrm{NaCl}$, $5 \mathrm{mM} \mathrm{CaCl}_{2}$, and $0.02 \% \mathrm{NaN}_{3}$, and then SDS-PAGE was performed on a slab gel of 5\% acrylamide under reducing and nonreducing conditions. The gel was stained with $0.25 \%$ Coomassie brilliant blue solution containing 9.2\% acetic acid and $45.4 \%$ methanol to visualize collagens.

Statistical Analysis — Data were analyzed for statistical significance using ANOVA and Bonferroni's multiple $t$-test. $p$-Values of less than 0.05 were considered to indicate statistically significant differences.

\section{RESULTS}

\section{Expression of Endogenous TNF- $\alpha$ in Vascular Smooth Muscle Cells}

First, expression of endogenous TNF- $\alpha$ in bovine aortic smooth muscle cells was determined by immunocytochemistry, RT-PCR followed by Southern blot analysis, and Western blot analysis. As
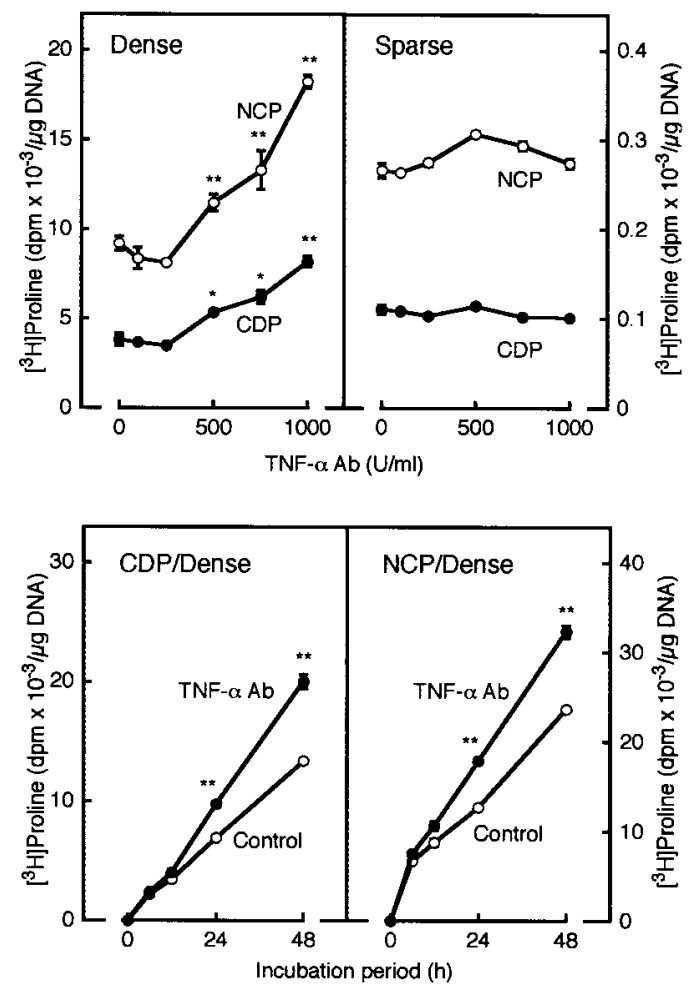

Fig. 2. Incorporation of $\left[{ }^{3} \mathrm{H}\right]$ Proline into CDP and NCP of Dense and Sparse Vascular Smooth Muscle Cells Treated with TNF- $\alpha \mathrm{Ab}$

Dense and sparse cultures of bovine aortic smooth muscle cells were incubated at $37^{\circ} \mathrm{C}$ for $6,12,24$, or $48 \mathrm{hr}$ with TNF- $\alpha \mathrm{Ab}(100,250,500$, 750 , or $1000 \mathrm{U} / \mathrm{ml}$ ) in the presence of $\left[{ }^{3} \mathrm{H}\right]$ proline. Values are means \pm S.E. of four samples. Significantly different from the corresponding control, ${ }^{*} p<0.05 ; * * p<0.01$.

shown in Fig. 1, the RT-PCR analysis showed the gene expression of TNF- $\alpha$ in dense vascular smooth muscle cells. Expression of TNF- $\alpha$ protein was confirmed by Western blot analysis. In addition, both dense and sparse cultures of the cells were immunostained with TNF- $\alpha$ Ab. These results clearly indicate that vascular smooth muscle cells express endogenous TNF- $\alpha$ in a cell density-independent manner.

\section{Regulation of CDP and NCP Synthesis by Endog- enous TNF- $\alpha$ in Vascular Smooth Muscle Cells}

Since it was shown that vascular smooth muscle cells express endogenous TNF- $\alpha$, we next investigated the regulation of collagen synthesis by the cytokine in the cells using TNF- $\alpha \mathrm{Ab}$ (Fig. 2). It was shown that TNF- $\alpha \mathrm{Ab}$ significantly increased the incorporation of $\left[{ }^{3} \mathrm{H}\right]$ proline into either $\mathrm{CDP}$ or $\mathrm{NCP}$ in a dose-dependent manner in dense vascular smooth muscle cells; the increase occurred after $24 \mathrm{hr}$ and longer. In contrast, the antibody failed to 
Table 1. Incorporation of $\left[{ }^{3} \mathrm{H}\right]$ Proline into CDP and NCP of Dense Vascular Smooth Muscle Cells Treated with TNF- $\alpha$ Ab or Rabbit IgG

\begin{tabular}{|c|c|c|}
\hline & $\begin{array}{c}\mathrm{CDP} \\
\left(\mathrm{dpm} \times 10^{-3} / \mu \mathrm{g} \mathrm{DNA}\right)\end{array}$ & $\begin{array}{c}\mathrm{NCP} \\
\left(\mathrm{dpm} \times 10^{-3} / \mu \mathrm{g} \mathrm{DNA}\right)\end{array}$ \\
\hline \multicolumn{3}{|c|}{ Bovine aortic smooth muscle cells } \\
\hline Control & $4.45 \pm 0.08$ & $9.37 \pm 0.08$ \\
\hline $\mathrm{TNF}-\alpha \mathrm{Ab}$ & $6.20 \pm 0.23 * *$ & $13.07 \pm 0.42 * *$ \\
\hline Rabbit IgG & $4.37 \pm 0.04$ & $10.20 \pm 0.18$ \\
\hline \multicolumn{3}{|c|}{ Human aortic smooth muscle cells } \\
\hline Control & $9.97 \pm 0.13$ & $32.54 \pm 0.24$ \\
\hline TNF- $\alpha \mathrm{Ab}$ & $12.29 \pm 0.26^{*}$ & $38.68 \pm 0.99 *$ \\
\hline Rabbit IgG & $9.74 \pm 0.24$ & $32.85 \pm 0.63$ \\
\hline \multicolumn{3}{|c|}{ Rabbit aortic smooth muscle cells } \\
\hline Control & $23.45 \pm 0.65$ & $37.35 \pm 0.83$ \\
\hline $\mathrm{TNF}-\alpha \mathrm{Ab}$ & $29.83 \pm 0.42 *$ & $45.73 \pm 0.24^{*}$ \\
\hline Rabbit IgG & $26.00 \pm 0.65$ & $42.38 \pm 0.89$ \\
\hline
\end{tabular}

increase the $\left[{ }^{3} \mathrm{H}\right]$ proline incorporation in the sparse cells. Thus it is suggested that endogenous TNF- $\alpha$ suppresses the synthesis of collagens and NCP in vascular smooth muscle cells only when the cell density is high.

In addition, the increase in the $\left[{ }^{3} \mathrm{H}\right]$ proline incorporation into CDP and NCP by TNF- $\alpha \mathrm{Ab}$ was observed not only in bovine aortic smooth muscle cells but also in human and rabbit aortic smooth muscle cells (Table 1), suggesting that there is no species-related difference in the regulation of collagen and NCP synthesis by endogenous TNF- $\alpha$ in this cell type.

\section{Interaction of Endogenous TNF- $\alpha$ with TGF- $\beta$ on CDP and NCP Synthesis in Vascular Smooth Muscle Cells}

TGF- $\beta$ is a cytokine that strongly promotes the synthesis of collagen in vascular smooth muscle cells. ${ }^{27)}$ Figure 3 shows the interaction of TNF- $\alpha \mathrm{Ab}$ with TGF- $\beta$ in the $\left[{ }^{3} \mathrm{H}\right]$ proline incorporation into CDP and NCP in dense and sparse cultures of bovine aortic smooth muscle cells. In the dense cells, not only TNF- $\alpha$ but also TGF- $\beta$ alone significantly increased the $\left[{ }^{3} \mathrm{H}\right]$ proline incorporation into $\mathrm{CDP}$ and NCP. The increase in the synthesis of $\left[{ }^{3} \mathrm{H}\right]$ prolinelabeled CDP by TNF- $\alpha$ Ab was observed in the presence or absence of TGF- $\beta$, suggesting that endogenous TNF- $\alpha$ has a suppressive effect on TGF- $\beta$-induced collagen synthesis in dense vascular smooth muscle cells. In the sparse cells, TGF- $\beta$ alone also
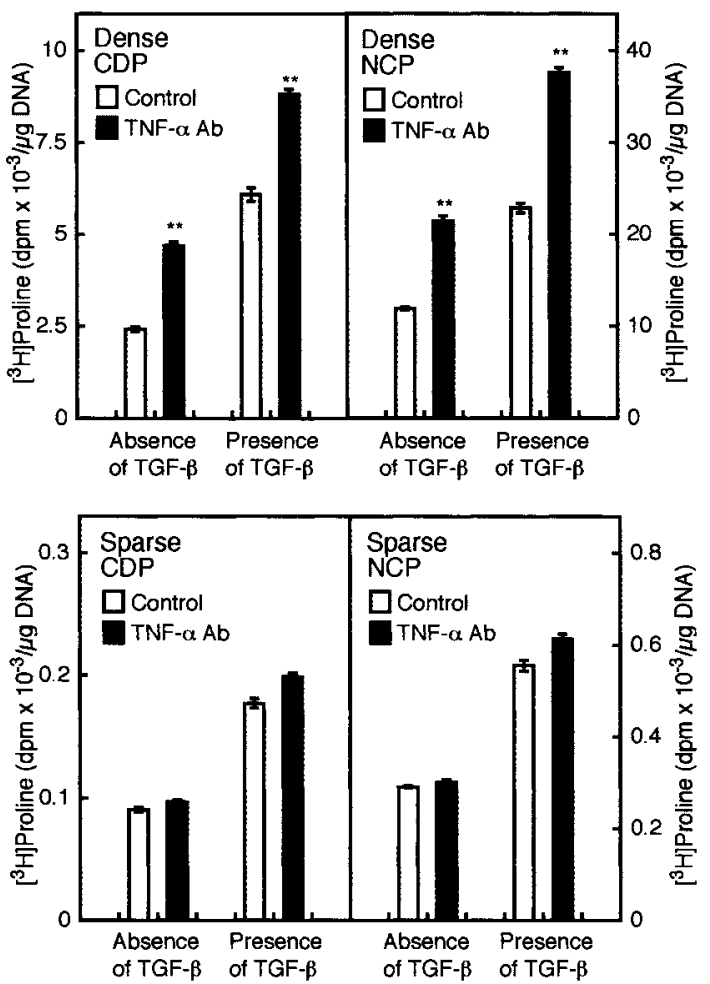

Fig. 3. Interaction of TNF- $\alpha \mathrm{Ab}$ with TGF- $\beta$ in the Incorporation of $\left[{ }^{3} \mathrm{H}\right]$ proline into CDP and NCP of Dense and Sparse Vascular Smooth Muscle Cells

Dense and sparse cultures of bovine aortic smooth muscle cells were incubated at $37^{\circ} \mathrm{C}$ for $24 \mathrm{hr}$ with TNF- $\alpha \mathrm{Ab}(1000 \mathrm{U} / \mathrm{ml})$ and/or TGF- $\beta$ $(10 \mathrm{ng} / \mathrm{ml})$ in the presence of $\left[{ }^{3} \mathrm{H}\right]$ proline. Values are means \pm S.E. of four samples. $* *$ Significantly different from the corresponding control, $p<0.01$. 


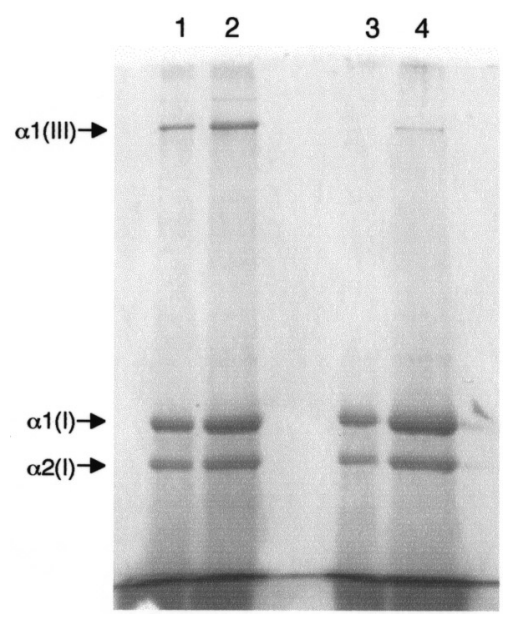

Fig. 4. SDS-PAGE of Collagens Synthesized by Dense Vascular Smooth Muscle Cells Treated with TNF- $\alpha \mathrm{Ab}$

Dense cultures of bovine aortic smooth muscle cells were incubated at $37^{\circ} \mathrm{C}$ for $24 \mathrm{hr}$ with TNF- $\alpha \mathrm{Ab}(1000 \mathrm{U} / \mathrm{ml})$. Lanes 1 and 3, control; lanes 2 and $4, \mathrm{TNF}-\alpha \mathrm{Ab}$ treatment; lanes 1 and 2, nonreducing conditions; lanes 3 and 4, reducing conditions by dithiothreitol.

significantly increased the $\left[{ }^{3} \mathrm{H}\right]$ proline incorporation into CDP and NCP. However, TNF- $\alpha$ Ab failed to change the $\left[{ }^{3} \mathrm{H}\right]$ proline incorporation in the presence or absence of TGF- $\beta$.

\section{Endogenous TNF- $\alpha$ Suppresses the Synthesis of Types I and III Collagens}

Figure 4 shows SDS-PAGE results of collagens synthesized by dense cultures of bovine aortic smooth muscle cells after treatment with TNF- $\alpha \mathrm{Ab}$. In this experiment, types I and III collagen were detected as $\alpha 1(\mathrm{I}), \alpha 2(\mathrm{I})$, and $\alpha 1(\mathrm{III})$. TNF- $\alpha \mathrm{Ab}$ increased both types of collagens, suggesting that endogenous TNF- $\alpha$ suppresses all collagen synthesis in dense vascular smooth muscle cells.

\section{DISCUSSION}

In the present study, we demonstrated that cultured vascular smooth muscle cells constitutively express TNF- $\alpha$ in a cell density-independent manner. There are two different phenotypes in this cell type ${ }^{28)}$; one is known as the synthetic phenotype, characterized by well-developed rough endoplasmic reticulum, Golgi apparatus and many ribosomes, and the other is the contractile phenotype, characterized by a large amount of myofilaments. Cultured vascular smooth muscle cells also can change their phenotype from a synthetic to a contractile state, although most of them are the synthetic phenotype for at least 3 days after reaching confluence. ${ }^{29)}$ Since the cells were used before and just after reaching confluence in the present study, they are postulated to have the characteristics of the synthetic phenotype. Thus the present data suggest that the synthetic phenotype of vascular smooth muscle cells expresses TNF- $\alpha$ regardless of cell density. However, promotion of collagen synthesis by TNF- $\alpha \mathrm{Ab}$ occurred only in the dense cells, indicating that collagen synthesis is regulated by endogenous TNF- $\alpha$ only when the cell density is high. Our previous study showed that specific binding of TNF- $\alpha$ is not different between dense and sparse vascular smooth muscle cells, ${ }^{20)}$ but TNF- $\alpha$ Ab promotes DNA synthesis. ${ }^{30)}$ Those results and the present data indicate that the expression of endogenous TNF- $\alpha$ is cell density independent but the functional regulation by endogenous and exogenous TNF- $\alpha$ is cell density dependent in vascular smooth muscle cells.

Excessive deposition of extracellular matrix components such as collagens synthesized by the synthetic phenotype of vascular smooth muscle cells in the intima is postulated to be one of the most important pathological changes in atherosclerosis. ${ }^{1,10,14,16)}$ In our previous study, it was shown that exogenously added TNF- $\alpha$ suppresses the synthesis of collagen in cultured vascular smooth muscle cells. ${ }^{20)}$ The suppression is cell density and cell type dependent; dense vascular smooth muscle cells were much more sensitive than the sparse cells, and vascular endothelial collagen synthesis is not suppressed by TNF- $\alpha$. In addition, the suppression occurs in minor collagens such as types IV and V rather than in predominant collagens such as types I and III in dense vascular smooth muscle cells. In the present study, it was suggested that endogenous TNF- $\alpha$ also suppresses all collagen synthesis in dense vascular smooth muscle cells, although minor collagens could not be detected. The previous and present results are consistent with one another as regards the suppressive effect of TNF- $\alpha$ on all collagen synthesis in dense vascular smooth muscle cells. It is a novel finding of the present study that cell density-dependent regulation of collagen synthesis by TNF- $\alpha$ is possible in vascular smooth muscle cells in an autocrine mechanism as well as in a paracrine mechanism without species-related differences.

It was suggested that endogenous TNF- $\alpha$ suppresses the collagen synthesis induced by TGF- $\beta$. TGF- $\beta$ is a cytokine that is involved in the excess accumulation of extracellular matrix such as collagens in atherosclerotic plaque. ${ }^{31)}$ It has been pos- 
tulated that the main source of TGF- $\beta$ is platelets and macrophages ${ }^{27)}$ and that of collagens is the synthetic phenotype of vascular smooth muscle cells accumulated in the plaque. ${ }^{12)}$ Thus the present data suggest the possibility that TNF- $\alpha$ expressed by vascular smooth muscle cells can contribute to prevention of the progression of atherosclerosis through suppression of collagen synthesis after the cell density has become high in the plaque. Our recent data that suggested an inhibitory effect of endogenous and exogenous TNF- $\alpha$ on vascular smooth muscle cell growth when the cell density is high ${ }^{30)}$ support this hypothesis. Regulation of endogenous TNF- $\alpha$ expression in vascular smooth muscle cells should be clarified to address the hypothesis. In addition, it is unclear whether the endogenous TNF- $\alpha$ derived from vascular smooth muscle cells in the plaque can exhibit cytotoxicity to vascular endothelial cells like exogenous TNF- $\alpha .{ }^{2)}$

In conclusion, the present data suggest that the synthetic phenotype of vascular smooth muscle cells in general express TNF- $\alpha$ regardless of the cell density and the origin of species, and that the endogenous cytokine mediates the suppression of all collagen synthesis via an autocrine mechanism only when the cell density is high. The suppression occurred even when the cells were stimulated with TGF- $\beta$, suggesting that endogenous TNF- $\alpha$ of vascular smooth muscle cells may be involved in the progression of atherosclerosis after the cell density became high in the plaqus. Although cell densitydependent regulation has been observed in the effect of TGF- $\beta$ on the growth of vascular smooth muscle cells ${ }^{32}$ and on the proteoglycan synthesis of vascular endothelial cells, ${ }^{33)}$ it was shown that regulation of collagen synthesis by endogenous TNF- $\alpha$ is also cell density dependent. Regulation of endogenous TNF- $\alpha$ expression in vascular smooth muscle cells should be clarified to understand the involvement of the cytokine in the progression and formation of atherosclerosis. In addition, we propose a possibility that the contractile phenotype of vascular smooth muscle cells also expresses TNF- $\alpha$, of which the role may be to contribute to the physiological maintenance of the growth-arrested cells in the medial layer of blood vessels.

Acknowledgements This work was supported in part by the Specific Research Fund of Hokuriku University (to T. K.).

\section{REFERENCES}

1) Ross, R. (1993) The pathogenesis of atherosclerosis: a perspective for the 1990s. Nature (London), 362, 801-809.

2) Estrada, C., Martin, G. C., Mincada, S. and Gonzalez, C. (1992) Nitric oxide mediates tumor necrosis factor alpha cytotoxicity in endothelial cells. Biochem. Biophys. Res. Commun., 189, 475-482.

3) Schleef, R. R., Bevilacqua, M. P., Sawdy, M., Gimbrone, M. A. and Loskutoff, D. J. (1988) Cytokine activation of vascular endothelium: effects on tissue-type plasminogen activator and type-1 plasminogen activator inhibitor. J. Biol. Chem., 263, 5797-5803.

4) Libby, P., Ordovas, J. M., Auger, K. R., Robbins, A. H., Birinyi, L. K. and Dinarello, C. A. (1986) Endotoxin and tumor necrosis factor induce interleukin1 gene expression in adult human vascular endothelial cells. Am. J. Pathol., 124, 179-185.

5) Barath, P., Fishbein, M. C., Cao, J., Berenson, J., Helfant, R. H. and Forrester, J. S. (1990) Detection and localization of tumor necrosis factor in human atheroma. Am. J. Cardiol., 65, 297-302.

6) Barath, P., Fishbein, M. C., Cao, J., Berenson, J., Helfant, R. H. and Forrester, J. S. (1990) Tumor necrosis factor gene expression in human vascular intimal smooth muscle cells detected by in-situ hybridization. Am. J. Pathol., 137, 503-509.

7) Lei, X. and Buja, M. (1996) Detection and localization of tumor necrosis factor-alpha in WHHL rabbit arteries. Atherosclerosis, 125, 81-89.

8) Tanaka, H., Swanson, S. J., Sukhova, G., Schoen, F. J. and Libby, P. (1995) Smooth muscle cells of the coronary arterial tumica media express tumor necrosis factor- $\alpha$ and proliferate during acute rejection of rabbit cardiac allografts. Am. J. Pathol., 147, 617-626.

9) Warner, S. J. C. and Libby, P. (1989) Human vascular smooth muscle cells. J. Immunol., 142, 100-109.

10) Burke, J. M. and Ross, R. (1979) Synthesis of connective tissue macromolecules by smooth muscle. Connect. Tissue Res., 8, 119-157.

11) Voss, B. and Rauterberg, J. (1987) Localization of collagen types I, III, IV and V, fibronectin and laminin in human arteries by the indirect immunofluorescence method. Pathol. Res. Pract., 187, 568575.

12) Mayne, R. (1986) Collagenous proteins of blood vessels. Arteriosclerosis, 6, 585-593.

13) Barnes, M. J. (1985) Collagens in atherosclerosis. Coll. Relat. Res., 5, 65-97.

14) McCullagh, K. A. and Ehehast, L. A. (1974) Increased arterial collagen synthesis in experimental 
canine atherosculerosis. Atherosclerosis, 19, 13-28.

15) Katsuda, S., Okada, Y., Minamoto, T., Oda, Y., Matsui, Y. and Nakanishi, I. (1992) Collagens in human atherosclerosis. Immunohistochemical analysis using collagen type-specific antibodies. $J$. Atheroscler. Thromb., 12, 494-502.

16) Barnes, M. J. (1983) Collagen polymorphism in the normal and diseased blood vessel wall. Atherosclerosis, 46, 249-251.

17) McCullagh, K. A. and Balian, G. (1975) Collagen characterisation and cell transformation in human atherosclerosis. Nature (London), 25, 73-75.

18) Kaji, T., Hiraga, S., Yamamoto, C., Sakamoto, M., Nakashima, Y., Sueishi, K. and Koizumi, F. (1993) Tumor necrosis factor alpha-induced alteration of glycosaminoglycans in cultured vascular smoothmuscle cells. Biochim. Biophys. Acta, 1176, 20-26.

19) Kaji, T., Hiraga, S., Yamamoto, C., Okoshi, T., Sakamoto, S., Kozuka, H. and Koizumi, F. (1993) Characterization of tumor necrosis factor alpha-induced alteration of glycosaminoglycans in cultured cells: Comparison among vascular smooth-muscle cells, vascular endothelial cells, Chang liver cells and LLC-PK1 cells. Biol. Pharm. Bull., 16, 834839.

20) Hiraga, S., Kaji, T., Ueda, Y., Zisaki, F., Iwata, K., Koizumi, F., Okada, Y., Katsuda, S. and Nakanishi, I. (2000) Modulation of collagen synthesis by tumor necrosis factor alpha in cultured vascular smooth muscle cells. Life Sci., 66, 235-244.

21) Okada, Y., Katsuda, S., Matsui, Y., Minamoto, T., and Nakanishi, I. (1989) Altered synthesis of collagen types in cultured arterial smooth muscle cells during phenotypic modulation by dimethyl sulfoxide. Acta Pathol. Jpn., 39, 15-22.

22) Iruela-Arispe, M. L., Hasselaar, P. and Sage, H. (1991) Differential expression of extracellular proteins is correlated with angiogenesis in vitro. $L a b$. Invest., 64, 174-186.

23) Laemmli, U. K. (1970) Cleavage of structural proteins during the assembly of the head of bacteriophage T4. Nature (London), 277, 680-685.

24) Peterkofsky, B. and Diegelman, R. F. (1971) Use of a mixture of proteinase-free collagenases for the specific assay of radioactive collagen in the presence of other proteins. Biochemistry, 10, 988-994.

25) Kissane, J. M. and Robins, E. (1958) The fluoro- metric measurement of deoxyribonucleic acid in animal tissues with special reference to the central nervous system. J. Biol. Chem., 233, 184-188.

26) Hata, R. I. and Senoo, H. (1989) L-ascorbic acid 2phosohate stimulates collagen accumulation, cell proliferation, and formation of a three-dimensional tissuelike substance by skin fibroblasts. J. Cell. Physiol., 138, 8-16.

27) Davidson, J. M., Zoia, O. and Liu, J. M. (1993) Modulation of transforming growth factor-beta 1 stimulated elastin and collagen production and proliferation in porcine vascular smooth muscle cells and skin fibroblasts by basic fibroblast growth factor, transforming growth factor-alpha, and insulinlike growth factor-I. J. Cell. Physiol., 155, 149-156.

28) Chamley-Campbell, J. H., Champbell, G. R. and Ross, R. (1979) The smooth muscle cell in culture. Physiol.Rev., 59, 1-61.

29) Okada, Y., Katsuda, S., Matsui, Y., Watanabe, H., and Nakanishi, I. (1990) Collagen synthesis by cultured arterial smooth muscle cells during spontaneous phenotypic modulation. Acta Pathol. Jpn., 40, 157-164.

30) Kaji, T., Hiraga, S., Yamamoto, C., Fujiwara, Y., Ueda, Y., Zisaki, F., Iwata, K., Okada, Y. and Katsuda, S. (2002) Effects of tumor necrosis factor$\alpha$ on the synthesis of DNA, the secretion of matrix metalloproteinase/tissue inhibitors of metalloproteinase, and the activity of invasive migration in cultured vascular smooth muscle cells. $J$. Health Sci., 48, 354-358.

31) Bahadori, L., Milder, J., Gold, L. and Botney, M. (1995) Active macrophage-associated TGF-beta colocalizes with type I procollagen gene expression in atherosclerotic human pulmonary arteries. Am. J. Pathol., 146, 1140-1149.

32) Majack, R. A. (1987) Beta-type transforming growth factor specifies organizational behavior in vascular smooth muscle cell cultures. J. Cell Biol., 105, 465471.

33) Kaji, T., Yamada, A., Miyajima, S., Yamamoto, C., Fujiwara, Y., Wight, T. N. and Kinsella, M. G. (2000) Cell density-dependent regulation of proteoglycan synthesis by transforming growth factor- $\alpha 1$ in cultured bovine aortic endothelial cells. J. Biol. Chem., 275, 1463-1470. 